\title{
Studi Daya Hambat In Vitro Anti MPS ecto CIK (Mayor Physiological Protein Substrat) terhadap Viabilitas Spermatozoa Kambing Dan Domba
}

\author{
Bayyinatul Muchtaromah
}

Dosen Jurusan Biologi Fakultas Sains dan Teknologi

Universitas Islam Negeri Maulana Malik Ibrahim Malang

\begin{abstract}
ABSTRAK
Untuk menuju suatu penemuan tentang vaksin kontrasepsi bagi pria, diperlukan penelitian dasar mengenai hal tersebut. Sebagai langkah awal dilakukan uji hambatan Anti MPS ecto CIK terhadap viabilitas spermatozoa kambing dan domba, sedangkan dari penelitian pendahuluan diketahui bahwa anti MPS dari ecto-CIK ini mampu bereaksi silang dengan spermatozoa domba, dan sapi. Berdasarkan hal tersebut peneliti tertarik untuk mengetahui seberapa besar peranan anti MPS ecto CIK dalam menghambat viabilitas spermatozoa kambing dan domba secara in vitro.

Tujuan dari penelitian ini adalah mengetahui seberapa besar peranan anti MPS ecto CIK dengan pemberian perlakuan konsentrasi dan lama inkubasi serta interaksi kedua perlakuan dalam menghambat viabilitas spermatozoa kambing dan domba. Rancangan penelitian yang digunakan adalah rancangan acak lengkap (RAL) dengan pola faktorial yang terdiri atas 2 faktor utama, faktor pertama yaitu: dosis

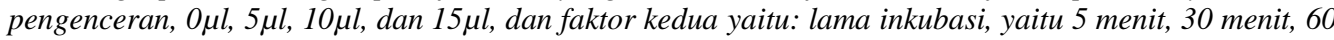
menit, dan 120 menit, masing-masing 6 kali ulangan. Data viabilitas spermatozoa kambing dan domba dianalisis dengan Uji one way ANOVA, jika hasil dari analisis tersebut terdapat pengaruh yang nyata maka akan dilanjutkan dengan Uji Jarak Berganda Duncan dengan taraf signifikansi 5\% (0,05).

Pemberian perlakuan anti MPS dari ecto CIK membran spermatozoa kambing dengan konsentrasi dan 0 $\mu l, 5 \mu l, 10 \mu l, 15 \mu l$ dan lama inkubasi 5 menit, 30 menit, 60 menit dan 120 menit berpengaruh signifikan dalam menghambat viabilitas spermatozoa kambing dan domba. Pada perlakuan anti MPS ecto CIK dengan konsentrasi $15 \mu \mathrm{l}$ dan lama inkubasi 120 menit merupakan perlakuan yang paling optimal dalam menghambat viabilitas spermatozoa kambing $(45,50 \pm 11,16 \% ; 44,87 \pm 9,40 \%)$ dan domba $(55,54 \pm 18,87 \% ; 40,58 \pm 13,20 \%)$. Interaksi pemberian perlakuan konsentrasi dan lama inkubasi anti MPS ecto CIK pada konsentrasi $15 \mu \mathrm{l}$ dan lama inkubasi 120 menit anti MPS ecto CIK paling berpengaruh dalam menghambat viabilitas spermatozoa domba $(26,83 \pm 8,70 \%)$, sedangkan pada kambing tidak berpengaruh.
\end{abstract}

Kata kunci: Daya Hambat, Anti MPS ecto CIK, Viabilitas Spermatozoa

\section{Latar Belakang}

Salah satu penelitian tentang protein membran spermatozoa kambing dilakukan oleh Maiti, et al., (2004), dari penelitian tersebut ditemukan letak Mayor Physiological Protein Substrat (MPS) dari ecto cyclic AMP independent serin/theonin protein kinase (ecto-CIK) pada permukaan luar spermatozoa kambing yang telah mengalami maturasi. Hasil purifikasi dan karakterisasi menunjukkan bahwa protein MPS dari ecto-CIK tersebut mempunyai berat molekul 100 $\mathrm{kDa}$, dengan tiga titik elektrik 6,$37 ; 6,05$ dan 5,14.serta Fraksi complement dan Fraksi antibodi dari anti MPS ecto CIK dapat menyebabkan penghambatan motilitas spermatozoa kambing

Untuk menuju suatu penemuan tentang vaksin kontrasepsi bagi pria, diperlukan penelitian dasar mengenai hal tersebut. Sebagai langkah awal dilakukan uji hambatan Anti MPS dari ecto-CIK terhadap viabilitas spermatozoa kambing, domba dan sapi, sedangkan dari penelitian pendahuluan diketahui bahwa anti MPS dari ecto-CIK ini mampu bereaksi silang dengan spermatozoa domba, dan sapi. Berdasarkan hal tersebut peneliti tertarik untuk mengetahui seberapa besar peranan anti MPS ecto
CIK dalam menghambat viabilitas spermatozoa kambing dan domba secara in vitro.

\section{Metode Penelitian \\ Jenis dan Rancangan Penelitian}

Penelitian ini menggunakan rancangan acak lengkap (RAL) pola faktorial yang terdiri atas 2 faktor, faktor pertama yaitu: dosis pengenceran, $0 \mu \mathrm{l}$, $5 \mu \mathrm{l}, 10 \mu \mathrm{l}$, dan $15 \mu \mathrm{l}$, dan faktor kedua yaitu: lama inkubasi, yaitu 5 menit, 30 menit, 60 menit, dan 120 menit, masing-masing 6 kali ulangan. Pengamatan viabilitas spermatozoa dengan menggunakan pewarnaan eosin negrosin dimana sampel diambil dari lima lapangan pandang dan dari tiap lapangan pandang tersebut diambil 100 ekor spermatozoa hidup dan mati dengan menggunakan sistem simple random sampling.

\section{Bahan dan Alat Penelitian Bahan Penelitian \\ Bahan yang dibutuhkan dalam penelitian ini adalah: Semen kambing dan domba, vaselin, air hangat, $\mathrm{NaCl}$ fisiologis $0,9 \%$, eosin negrosin, phosphat buffer saline, anti MPS ecto CIK.}




\section{Alat Penelitian}

Cover glass, objek glass, eppendorf, handly counter, seperangkat alat gelas, bunsen, water bath, mikropippet, tip, inkubator $\mathrm{CO}_{2}$, kertas tissue, ose, mikroskop cahaya,vorteks.

\section{Prosedur Penelitian}

Penampungan Semen Kambing, Domba dan Sapi Penampungan semen pada kambing dan domba dilakukan dengan menggunakan vagina buatan. Tempat penampungan maupun betina pemancing disiapkan dalam kondisi bersih. Pejantan yang akan ditampung dipersiapkan dengan membersihkan preputium dengan air kemudian dikeringkan. Vagina buatan yang telah dilengkapi dengan tabung penampung semen diisi dengan air hangat sampai mendapatkan suhu kira-kira $40^{\circ} \mathrm{C}$ dan sepertiga bagian depan selubung diberi vaselin. Penampungan semen dilakukan setelah 3-5 kali false mounting dan semen ejakulat pertama ditampung untuk diperiksa (Partodihardjo, 1992)

\section{Uji Kualitas Semen Segar}

Pemeriksaan kualitas meliputi pemeriksaan secara makroskopis dan mikroskopis dirujuk dari Partodihardjo (1992). Pemeriksaan secara makroskopis meliputi: volume, warna, $\mathrm{pH}$ serta uji kekentalan atau konsistensi. Volume diukur dengan melihat langsung pada tabung berskala warna dilihat langsung pada tabung penampung, pH diukur dengan menggunakan kertas lakmus yang kemudian dicocokkan dengan warna standar pada $\mathrm{pH}$ pen. Konsistensi diperiksa dengan menggoyangkan tabung berisi semen secara perlahan.

Pemeriksaan mikroskopis yang meliputi persentase motilitas individu, motilitas massa, uji viabilitas serta konsentrasi spermatozoa. Penentuan persentase motilitas individu spermatozoa dilakukan dengan melihat gerakan individu spermatozoa, yang diperiksa menggunakan mikroskop dengan pembesaran $400 \mathrm{x}$. Penilaian dilakukan dengan menghitung 100 spermatozoa yang bergerak aktif maju ke depan (gerakan maju progressif) dan dipersentasekan.

Motilitas massa dengan melihat gerakan spermatozoa yang berupa gelombang, dengan pembesaran $100 \mathrm{x}$. Penilaian sangat baik (+++) bila terlihat gelombang besar, banyak, gelap, jelas dan bergerak cepat; baik (++) bila terlihat gelombang kecil, tipis, jarang, kurang jelas dan bergerak lamban; sedang (+) bila terlihat gerak individu aktif progresif dan buruk; (0) tidak ada gerakan sama sekali.

Uji viabilitas spermatozoa dilakukan dengan pewarnaan eosin negrosin. Spermatozoa yang hidup tidak menyerap warna, sedangkan yang mati menyerap warna. Pengamatan menggunakan mikroskop cahaya dengan pembesaran 100x, dihitung sebanyak 100 spermatozoa, sehingga dapat diketahui proporsi spermatozoa yang hidup dan yang mati.

Pemeriksaan konsentrasi spermatozoa dilakukan menggunakan haemocytometer. Dengan cara pipet eritrosit yang berskala 0,5-101 dihubungkan dengan selang penghisap. Semen dihisap hingga skala 0,5 lalu diteruskan dengan $\mathrm{NaCl}$ fisiologis sampai pada skala 101. Setelah itu digoyang dengan gerakan menyerupai angka 8 selama 2-3 menit. Pada saat akan dilakukan perhitungan, beberapa tetes dibuang dan dikocok lagi. Selanjutnya " kamar hitung Neubauer" yang sudah dipasangi cover glass ditetesi isi pipet eritrosit. Kemudian gelas penutup ditekan perlahan. Perhitungan konsentrasi dengan menghitung lima kotak besar secara diagonal di bawah mikroskop dengan pembesaran $400 \mathrm{x}$.

\section{Pengamatan Inkubasi Spermatozoa dengan Anti MPS ecto CIK}

Setelah semen segar diuji kualitasnya dan memenuhi standar BBIB kemudian dilanjutkan dengan pengenceran menggunakan PBS sebanyak 4 kali dan dibagi menjadi 4 ependorf masing-masing ependorf berisi $80 \mu \mathrm{L}$ semen. Perlakuan 1: semen segar $+0 \mu \mathrm{L}$ anti MPS ecto CIK; perlakuan 2: semen segar $+5 \mu \mathrm{L}$ anti MPS ecto CIK, perlakuan 3: semen segar $+10 \mu \mathrm{L}$ anti MPS ecto CIK dan perlakuan 4: semen segar $+15 \mu \mathrm{L}$ anti MPS ecto CIK. Masing-masing perlakuan diinkubasi dalam inkubator $\mathrm{CO}_{2} 37^{\circ} \mathrm{C}$ selama 5, 30, 60 dan 120 menit. Masing-masing perlakuan diulang sebanyak 6 kali. Kemudian membuat preparat untuk mengamati viabilitas spermatozoa.

\section{Identifikasi Variabel \\ Variabel Bebas}

Variabel bebas penelitian ini adalah anti MPS ecto CIK dengan beberapa dosis, yaitu $(0 \mu 1$,

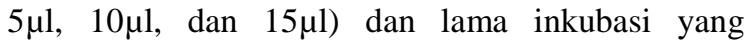
berbeda, yaitu (5 menit, 30 menit, 60 menit dan 120 menit) dengan menggunakan spermatozoa kambing dan domba

\section{Variabel Tergantung}

Variabel tergantung penelitian ini meliputi: persentase jumlah hidup mati spermatozoa kambing dan domba.

\section{Variabel Kendali}

Variabel kendali penelitian ini adalah kualitas motilitas individu spermatozoa dan hidup mati/viabilitas spermatozoa kambing dan domba.

\section{Teknik Analisis Data \\ Pengamatan Viabilitas Spermatozoa}

Uji viabilitas spermatozoa dilakukan dengan pewarnaan eosin negrosin. Caranya semen diteteskan pada obyek glass kemudian ditetesi eosin negrosin secukupnya, diaduk dengan cover glass 
agar bercampur dan didiamkan beberapa saat setelah itu dibuat apusan tipis dan difiksasi di atas api Bunsen. Spermatozoa yang hidup tidak menyerap warna, sedangkan yang mati menyerap warna. Pengamatan meggunakan mikroskop cahaya dengan pembesaran 100 kali, dihitung sebanyak 100 spermatozoa, sehingga dapat diketahui proporsi spermatozoa yang hidup dan mati (Partodihardjo, 1992).

\section{Analisis Data}

Data yang diperoleh dari eksperimental laboratorium berupa data persentase viabilitas spermatozoa kemudian dilakukan uji normalitas dan homogenitas, apabila memenuhi asumsi tersebut kemudian dilakukan Uji Anava. Jika terdapat perbedaan diantara perlakuan dilanjutkan dengan Uji Jarak Berganda Duncan (Duncan Multiple Range Test/DMRT) taraf signifikan 5\%.

Data yang diperoleh melalui hasil pengamatan ditabulasi dan dianalisis secara statistik dengan Uji ANOVA dua jalur, jika hasil dari analisis tersebut terdapat pengaruh yang nyata maka akan dilanjutkan dengan Uji Jarak Duncan dengan taraf signifikansi 5\% $(0,05)$.

\section{Hasil dan Pembahasan}

\section{Kualitas Spermatozoa Kambing, Domba, dan} Sapi pada Semen Segar

Pemeriksaaan makroskopis meliputi volume, warna, bau, dan viskositas, sedangkan pemeriksaan mikroskopis meliputi motilitas massa, motilitas individu, viabilitas, dan konsentrasi. Hasil pemeriksaan semen segar kambing, domba dan sapi dapat dilihat pada Tabel 1 .

Tabel 1. Hasil Pemeriksaan Semen segar Kambing, Domba, dan Sapi

\begin{tabular}{ccc}
\hline Param & \multicolumn{2}{c}{ Semen Segar } \\
\cline { 2 - 3 } eter & Kambing $( \pm$ SD $)$ & Domba $( \pm$ SD $)$ \\
\hline & $0,65 \pm 0,21$ & $0,95 \pm 0,26$ \\
& $68,75 \pm 8,50$ & $77,08 \pm 5,88$ \\
& $2+$ & $3+$ \\
& $61,46 \pm 11,01$ & $69,00 \pm 12,58$ \\
& Krem & Krem \\
& Kental & Kental \\
& $2495,50 \pm 331,17$ & $2514,50 \pm 778,5$ \\
\hline
\end{tabular}

Hasil tersebut menunjukkan bahwa semen segar yang digunakan dalam penelitian ini masih dalam kisaran normal. Volume semen kambing per ejakulasi pada penelitian ini didapatkan 0,65 $\pm 0,21$ cc, Menurut Toelihere (1985) semen kambing di daerah tropis berkisar 0,5-1,0 cc atau 0,3-1,5 cc (Garner dan Hafez, 2000), sedangkan sesuai dengan pendapat Toelihere (1985) bahwa volume semen domba $0,95 \pm 0,26 \mathrm{cc}$, karena semen domba normal berkisar antara 1-3 cc (Toelihere, 1985).

Motilitas individu semen kambing 68,75 \pm $8,50 \%$ sesuai dengan pernyataan Garner dan Hafez, (2000) bahwa motilitas semen kambing berkisar 60$80 \%$ per ejakulasi, sedangkan motilitas individu semen domba berkisar 77,08 $\pm 5,88 \%$.

Warna semen kambing pada umumnya krem keputihan (Evans dan Maxwell, 1987) atau bervariasi sampai krem kekuningan karena banyak mengandung riboflavin dari sekresi kelenjar vesíkula, sedangkan seman Domba berwarna Krem, hal ini sesuai dengan pendapat Toelihere, (1993) semen domba yang baik berwarna krem (Foote, 1986) atau putih susu dan bervariasi sampai berwarna krem (Partodihardjo, 1992). Konsentrasi spermatozoa segar kambing sebesar 2495,50 \pm $331,17.10^{6} / \mathrm{ml}$, konsentrasi tersebut masih dalam kisaran normal sesuai dengan pendapat Davendra dan Burns (1994) bahwa konsentrasi semen segar kambing per ejakulat sebesar 1,8-4.10 spermatozoa/ml, sedangkan konsentrasi spermatozoa segar domba $2514,50 \pm 778,5.10^{6} / \mathrm{ml}$ hal ini masih dalam kisaran normal antara 800-2000. $10^{6} / \mathrm{ml}$ (Garner dan Hafez, 2000).

\section{Analisis Perlakuan Anti MPS ecto CIK terhadap Viabilitas Spermatozoa Kambing \\ Pemberian perlakuan anti MPS ecto CIK} terhadap spermatozoa kambing dengan konsentrasi 0 $\mu \mathrm{l}, 5 \mu \mathrm{l}, 10 \mu \mathrm{l}, 15 \mu \mathrm{l}$ dan lama inkubasi 5 menit, 30 menit, 60 menit dan 120 menit mampu menghambat viabilitas spermatozoa kambing dengan hasil yang signifikan $(\mathrm{P}<0,05)$. Kemudian interaksi antara pemberian konsentrasi dan lama inkubasi anti MPS ecto CIK terhadap spermatozoa kambing menunjukkan hasil yang tidak signifikan $(\mathrm{P}>0,05)$ dalam menghambat viabilitas spermatozoa kambing.

Tabel notasi hasil uji lanjut jarak berganda Duncan anti MPS ecto CIK dalam menghambat viabilitas spermatozoa kambing, disajikan pada Tabel 2 berikut: 
Tabel 2. Notasi hasil uji lanjut jarak berganda Duncan anti MPS ecto CIK dalam menghambat viabilitas spermatozoa kambing

\begin{tabular}{|c|c|c|c|c|c|c|c|}
\hline \multicolumn{2}{|c|}{$\begin{array}{l}\text { Perlakuan } \\
\text { Konsentrasi } \\
\quad(\mu \mathrm{l})\end{array}$} & \multirow{2}{*}{$\begin{array}{l}\text { Rata-Rata (\%) } \\
61,46 \pm 11,01\end{array}$} & \multirow{2}{*}{$\begin{array}{l}\text { Notasi } \\
\mathrm{a}\end{array}$} & \multicolumn{2}{|c|}{$\begin{array}{c}\text { Perlakuan } \\
\text { Lama Inkubasi } \\
\text { (Menit) }\end{array}$} & Rata-Rata (\%) & Notasi \\
\hline $0 \mu l$ & A & & & 5 & $\mathrm{i}$ & $60,04 \pm 9,24$ & $\mathrm{a}$ \\
\hline $5 \mu l$ & B & $54,29 \pm 9,87$ & $\mathrm{~b}$ & 30 & ii & $56,46 \pm 11,10$ & $\mathrm{a}$ \\
\hline $10 \mu \mathrm{l}$ & $\mathrm{C}$ & $48,88 \pm 9,15$ & $\mathrm{c}$ & 60 & iii & $48,75 \pm 11,42$ & $\mathrm{~b}$ \\
\hline $15 \mu \mathrm{l}$ & $\mathrm{D}$ & $45,50 \pm 11,16$ & $\mathrm{c}$ & 120 & iiii & $44,87 \pm 9,40$ & $\mathrm{~b}$ \\
\hline
\end{tabular}

Hasil yang diperoleh dari notasi uji lanjut jarak berganda Duncan diketahui bahwa semakin besar pemberian konsentrasi dan lama inkubasi anti MPS ecto CIK terhadap spermatozoa kambing, semakin besar pula daya hambatnya terhadap viabilitas spermatozoa. Artinya dengan semakin ditingkatkan konsentrasi dan lama inkubasi anti MPS ecto CIK menunjukkan semakin sedikit persentase hidup spermatozoa kambing, tetapi persentase mati spermatozoa terlihat semakin besar. Kemudian dari tabel notasi di atas menunjukkan perlakuan konsentrasi $15 \mu \mathrm{l}(45,50 \pm 11,16 \%)$ dan lama inkubasi 120 menit $(44,87 \pm 9,40 \%)$ mempunyai daya hambat yang paling signifikan

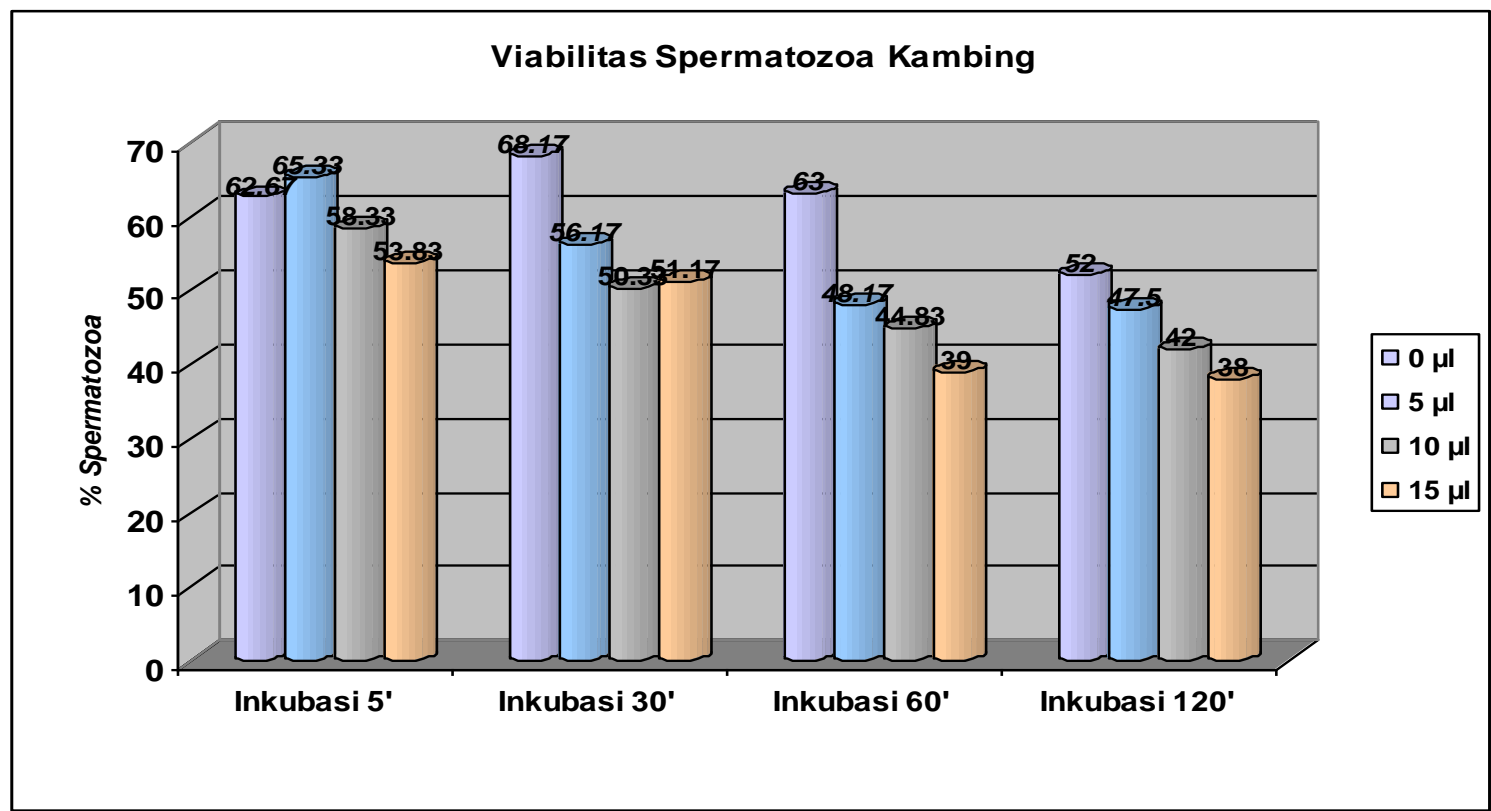

Gambar 1. Grafik hasil persentase viabilitas spermatozoa kambing setelah pemberian perlakuan anti MPS ecto CIK.

\section{Analisis Perlakuan Anti MPS ecto CIK terhadap Viabilitas Spermatozoa Domba}

Dari pemberian perlakuan anti MPS ecto CIK terhadap spermatozoa domba dengan konsentrasi $0 \mu 1,5 \mu 1,10 \mu \mathrm{l}, 15 \mu \mathrm{l}$ dan lama inkubasi 5 menit, 30 menit, 60 menit dan 120 menit diketahui bahwa viabilitas spermatozoa domba dapat dihambat oleh anti MPS ecto CIK dengan hasil yang signifikan $(\mathrm{P}<0,05)$. Selanjutnya interaksi pemberian konsentrasi dan lama inkubasi anti MPS ecto CIK dalam menghambat viabilitas spermatozoa domba juga ditunjukkan dengan hasil yang signifikan $(\mathrm{P}<0,05)$.

Setelah data diketahui signifikan, maka dilanjutkan dengan uji jarak berganda duncan. Tabel hasil uji lanjut jarak berganda duncan kemampuan anti MPS ecto CIK dalam menghambat viabilitas spermatozoa domba dengan perlakuan konsentrasi 0 $\mu 1,5 \mu 1,10 \mu \mathrm{l}, 15 \mu \mathrm{l}$ dan lama inkubasi 5 menit, 30 menit, 60 menit dan 120 menit serta interaksi antara keduanya. Disajikan pada Tabel Berikut; 
Tabel 3 Notasi data hasil uji lanjut jarak berganda Duncan anti MPS ecto CIK dalam menghambat viabilitas spermatozoa domba

\begin{tabular}{ccccccccc}
\hline $\begin{array}{c}\text { Perlakuan } \\
\text { Konsentrasi }(\boldsymbol{\mu l})\end{array}$ & Rata-Rata (\%) & Notasi & \multicolumn{2}{c}{$\begin{array}{c}\text { Perlakuan Lama } \\
\text { Inkubasi (Menit) }\end{array}$} & Rata-Rata (\%) & Notasi \\
\hline $0 \quad \mu 1$ & A & $69,00 \pm 12,58$ & a & 5 & menit & i & $70,63 \pm 8,92$ & a \\
$5 \mu 1$ & B & $59,13 \pm 12,76$ & b & 30 menit & ii & $66,71 \pm 7,99$ & b \\
$10 \mu 1$ & C & $57,33 \pm 15,59$ & b & 60 menit iii & $63,08 \pm 12,16$ & bc \\
$15 \mu 1$ & D & $55,54 \pm 18,87$ & b & 120 menit iiii & $40,58 \pm 13,20$ & c
\end{tabular}

\begin{tabular}{|c|c|c|}
\hline $\begin{array}{c}\text { Interkasi lama*konsentrasi } \\
\text { viabilitas spermatozoa domba }\end{array}$ & Rata-rata & Notasi \\
\hline $\mathbf{A} *_{\mathbf{i}}$ & $77,17 \pm 7,88$ & $\mathrm{a}$ \\
\hline A*iii & $75,33 \pm 7,17$ & $a b$ \\
\hline $\mathbf{B} * \mathbf{i}$ & $73,00 \pm 8,92$ & $\mathrm{ab}$ \\
\hline A*ii & $70,17 \pm 8,84$ & $a b c$ \\
\hline D*ii & $70,00 \pm 7,69$ & $a b c$ \\
\hline $\mathbf{C} * \mathbf{i}$ & $67,67 \pm 9,63$ & $\mathrm{abc}$ \\
\hline B*ii & $65,67 \pm 6,50$ & $\mathrm{bc}$ \\
\hline C*iii & $65,33 \pm 11,22$ & $\mathrm{bc}$ \\
\hline $\mathbf{D} * \mathbf{i}$ & $64,67 \pm 4,50$ & bc \\
\hline C*ii & $61,00 \pm 6,81$ & $\mathrm{~cd}$ \\
\hline D*iii & $60,67 \pm 10,56$ & $\mathrm{~cd}$ \\
\hline A*iiii & $53,33 \pm 10,60$ & de \\
\hline B*iii & $51,00 \pm 4,82$ & de \\
\hline B*iiii & $46,83 \pm 7,83$ & $\mathrm{e}$ \\
\hline C*iiii & $35,33 \pm 7,12$ & $\mathrm{f}$ \\
\hline D*iiii & $26,83 \pm 8,70$ & $\mathrm{~g}$ \\
\hline
\end{tabular}

Kemudian dari hasil uji lanjut jarak berganda Duncan diketahui bahwa semakin besar pemberian konsentrasi dan lama inkubasi anti MPS ecto CIK terhadap spermatozoa domba maka semakin besar pula daya hambat yang diberikan terhadap viabilitas spermatozoanya, artinya dengan semakin ditingkatkan konsentrasi dan lama inkubasi anti MPS ecto CIK semakin sedikit persentase hidup spermatozoa domba dan persentase mati spermatozoa terlihat semakin besar. Dalam tabel di atas di tunjukkan perlakuan konsentrasi $15 \mu \mathrm{l}(55,54$ $\pm 18,87 \%)$ dan lama inkubasi 120 menit $(40,58 \pm$ $13,20 \%$ ) menjadi perlakuan hambatan anti MPS ecto CIK tehadap viabilitas spermatozoa domba yang paling signifikan. Selanjutnya interaksi pemberian konsentrasi $15 \mu \mathrm{l}$ anti MPS ecto CIK dengan lama inkubasi 120 menit $(26,83 \pm 8,70 \%)$ menjadi interaksi yang paling signifikan dalam menghambat viabilitas spermatozoa domba. Berikut disajikan grafik hasil persentase viabilitas spermatozoa domba setelah pemberian perlakuan anti MPS ecto CIK 


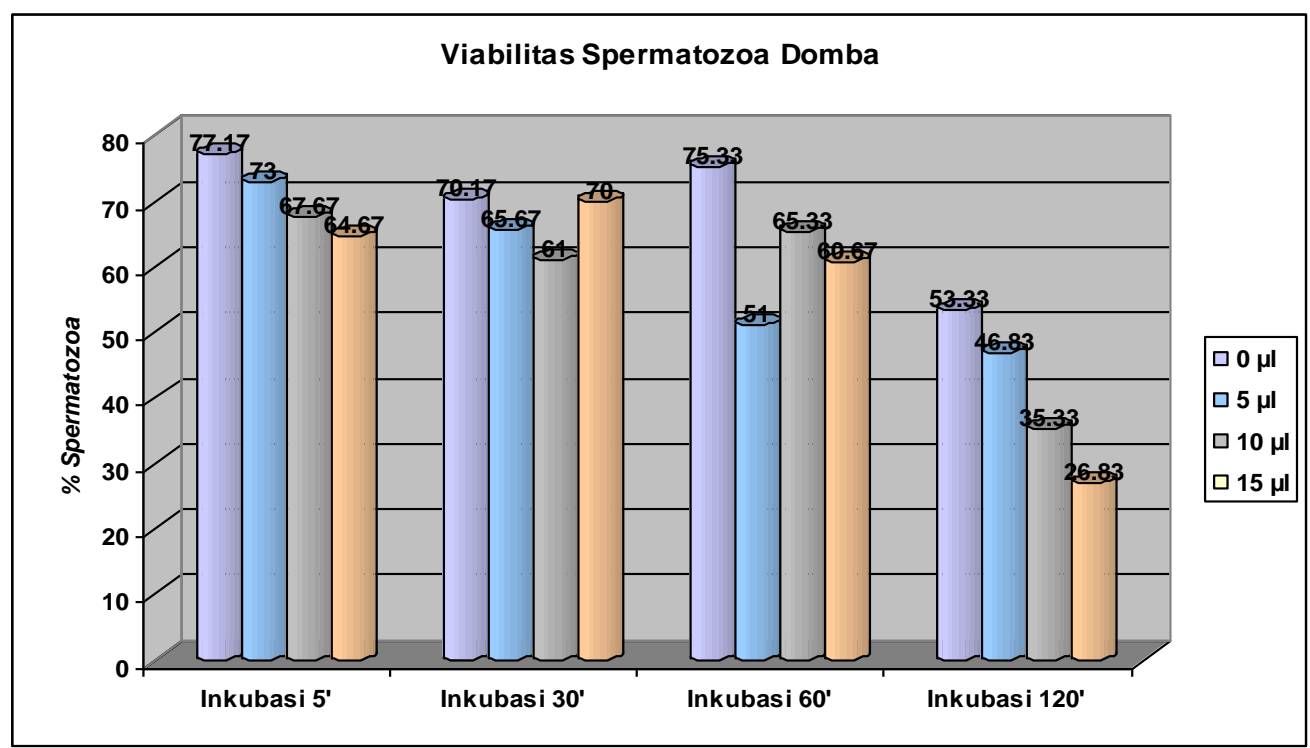

Gambar 2. Grafik hasil persentase viabilitas spermatozoa domba setelah pemberian perlakuan anti MPS ecto CIK.

Adapun dari tingkat pengaruh paling tinggi terhadap hidup mati spermatozoa ditunjukkan pada pemberian anti MPS ecto CIK terhadap viabilitas spermatozoa domba 40,58 $\pm 13,20 \%$ dan spermatozoa kambing 44,87 $\pm 9,40 \%$. Hidup mati spermatozoa dipengaruhi oleh dua faktor kemungkinan yang terjadi. Pertama, tingkat permeabilitas membran dan kedua proses menuju kapasitasi-reaksi akrosom. Spermatozoa yang sudah tua akan mengalami pengurangan permeabilitas pada membrannya, hal ini diakibatkan adanya denaturasi yaitu perubahan struktur protein membran yang rusak sehingga transport aktif dan transport pasif melalui membran spermatozoa tidak terjadi secara terpadu, akibatnya membran mengalami kerusakan dan semua materi yang ada di luar membran masuk memenuhi intra sel sehingga sel akan mati (Istanti dan Triastono, 1999).

Kedua, proses penting yang terjadi pada spermatozoa adalah kapasitasi dan rekasi akrosom. Keduanya berlangsung secara berurutan dari terjadinya kapasitasi yang ditandai dengan perubahan-perubahan dalam adenylate cyclase, perubahan pada metabolisme, serta perubahan dalam ion-ion intraseluler yang menyebabkan hilangnya kendali penjagaan gradien ion $\mathrm{Na}^{+} / \mathrm{K}^{+}$di sepanjang selaput plasma spermatozoa sehingga arus masuk besar-besaran dari $\mathrm{Ca}^{++}$ekstraseluler melalui selaput kepala spermatozoa sehingga menyulut terjadinya reaksi akrosom. Pada spermatozoa yang sekarat atau mati, ion-ion intraseluler akan mengalir keluar dan ion-ion eksternal sel berpenetrasi dengan bebas ke dalam sel. Hal ini disebabkan oleh lemahnya atau non aktifnya ATP-ase. Akrosin dan enzim-enzim akrosomal lainnya akan menyerang membran spermatozoa yang mengakibatkan hilangnya sebagian atau seluruh pembungkus akrosom (Susilowati, 2005). Dalam hal ini pengamatan hidup mati spermatozoa menggunakan pewarnaan eosin negrosin, spermatozoa mati berwarna merah, dan spermatozoa hidup berwarna putih atau tidak berwarna.

Interaksi pemberian perlakuan konsentrasi $15 \mu \mathrm{l}$ anti MPS ecto CIK dan lama inkubasi 120 menit terhadap spermatozoa domba $(26,83 \pm$ $8,70 \%$ ) merupakan interaksi yang paling tinggi pengaruhnya dalam menghambat viabilitas spermatozoanya. Adapun interaksi konsentrasi dan lama inkubasi anti MPS ecto CIK dalam menghambat viabilitas spermatozoa kambing tidak menunjukkan hasil yang signifikan $(\mathrm{P}>0,05)$. Tidak adanya interaksi konsentrasi dan lama inkubasi anti MPS ecto CIK dalam menghambat motilitas dan viabilitas spermatozoa kemungkinan besar disebabkan oleh awal perolehan semen yang diketahui dari uji motilitas dan viabilitas pada keadaan spermatozoa normal.

\section{Kesimpulan}

1. Pemberian perlakuan anti MPS ecto CIK dari ecto CIK dengan konsentrasi $0 \mu 1,5 \mu 1$, $10 \mu 1,15 \mu \mathrm{l}$ dapat menghambat viabilitas spermatozoa kambing dan domba. Perlakuan anti MPS ecto CIK dengan konsentrasi $15 \mu \mathrm{l}$ merupakan perlakuan yang paling optimal dalam menghambat viabilitas spermatozoa kambing (45,50 \pm $11,16 \%)$ dan domba $(55,54 \pm 18,87 \%)$.

2. Pemberian perlakuan anti MPS ecto CIK dari ecto CIK dengan lama inkubasi 5 menit, 30 menit, 60 menit dan 120 menit 
dapat menghambat viabilitas spermatozoa kambing dan domba $(\mathrm{P}<0,05)$. Perlakuan anti MPS ecto CIK dengan lama inkubasi 120 menit merupakan perlakuan yang paling optimal dalam menghambat viabilitas spermatozoa kambing (44,87 \pm $9,40 \%)$ dan domba $(40,58 \pm 13,20 \%)$

3. Interaksi pemberian perlakuan konsentrasi $15 \mu 1$ dan lama inkubasi 120 menit anti MPS ecto CIK merupakan interaksi yang paling tinggi pengaruhnya dalam menghambat viabilitas spermatozoa domba $(26,83 \pm 8,70 \%)$. Adapun interaksi konsentrasi dan lama inkubasi anti MPS ecto CIK dalam menghambat viabilitas spermatozoa kambing tidak menunjukkan hasil yang signifikan $(\mathrm{P}>0,05)$.

\section{Saran}

Diperlukan penelitian lebih lanjut tentang aplikasi anti MPS ecto CIK (Mayor Physiological protein Substrat) terhadap spermatozoa mamalia yang lain baik secara in vitro maupun secara in vivo.

\section{Daftar Pustaka}

Davendra, C. dan Burns, M., 1994. Produksi kambing di Daerah Tropis. Penerbit ITB. Bandung

Evans, G. dan Maxwell, W. M. C., 1987. Salomon's Artifical Insemination of Sheep and Goat. Butterworth. Sidney

Foote, R.H., 1986. Funcional Anatomy of Male Reproduction Dalam Reproduction in Farm Animal. Edisi VII. Dietit oleh Hafez, E. SE., 2000. Lea and Fabiger Publishing. Philadelphia.

Garner, D.L. dan Hafez, E.S.E., 2000. Spermatozoa and Seminal Plasma. Dalam Reproduction in Farm Animal. Edisi VII. Dietit oleh Hafez, E. SE., 2000. Lea and Fabiger Publishing. Philadelphia. Hal: 96109

Istanti, A \& Triastono, 1999. Biologi Sel. Universitas Negeri Malang. Fakultas Matematika dan IPA Jurusan Biologi. Malang.

Maiti, A., Mishra, KP. and Majumder, GC. 1992. Identification of Goat Sperm Ecto-Cyclic AMP Independent Protein Kinase Substrate Localized on Sperm Outer Surface. Departement of Atomic Energy, Bhabha Atomic Research Centre. Mumbai. India

Partodiharjo, Soebadi, 1992. Ilmu Reproduksi Hewan. Mutiara Sumber Widya. Jakarta Pusat. Cetakan ke III Hal 523-531.

Susilawati, Trinil. 2000. Fisiologi Spermatozoa: Kapasitasi, Reaksi Akrosom dan fertilisasi. Fakultas Peternakan Universitas Brawijaya Malang. Hal 2-4

Toelihere. 1985 . Fisiologi Reproduksi pada Ternak. Penerbit angkasa Bandung. Hal $93-115$.

Toelihere. 1993. Analisis Kualitas Semen pada Ternak. Penerbit angkasa Bandung 